\title{
Assessment of Effect of Hydropower Plant Projects on Socio- Environmental Sustenance and Development in Rwanda: A Review Done At Rubagabaga Hydropower Ltd.
}

\author{
Dr. MUTESI Jean Claude, Ph.D. \\ Ph.D. holder in Management- Finance Option, \\ Masters of Business Administration (Finance \& Accounting Option), \\ Post Graduate Diploma in Procurement \& Logistics and Supply Chain Management, \\ Post Graduate Diploma in Banking Management, B.S in Business Studies with Education, \\ Director of Budget and Finance of African Youth Commission (AYC) Lecturer at University of Kigali
}

(UoK).

\begin{abstract}
The study investigated the socio-economic and environmental impact of hydropower projects in Rwanda with a case study of Rubagabaga hydropower Ltd operating from Nyabihu District. It examines the impact of a socio-economic and environmental hydropower plant in Rwanda, identifies the challenge hydropower plants face in Rwanda, and finally investigates the relationship between hydro powers and their socio-economic impact in Rwanda? In this research, the quantitative research design is based on statistical data of the research that was used with quantitative and qualitative methods. Questionnaires were used to collect data. The target population of this study was made up of 252 participants including 154 respondents all from ten different villages surrounding the Rubagabaga plant in Nyabihu District. Data were analyzed using descriptive and correlation analysis and tables that were interpreted to confirm or deny the relevance of the main and specific objectives. Based on results from table no. 16 demonstrates that the beta $=0.397$ with the $t$ value of 2.333 and the $\mathrm{p}$-value of 0.021 . Since the p-value is less than 0.05 , the researcher rejected the null hypothesis and considered it an alternate. There is a strong positive relationship between environmental assessment of hydropower plant projects and socio-environmental sustenance and development. In a nutshell, the researcher has rejected the null hypothesis and considered its alternate. Community structure and dynamics have a positive influence on socio-environmental sustenance and development. Table no.16 shows that beta $=0.341$ with the $\mathrm{t}$ value of 2.668 as the p-value was 0.009 . Since the p-value is less than 0.05 . Therefore, the researcher rejected the null hypothesis and considered it an alternate. According to table no.21, the changes in community structure and dynamics of the hydropower plant project cause the increase of $0.341(34.1 \%)$ of the socio-environment sustenance and development. The ratio of beta modal results for the $t$ value expressed $\mathrm{t}=2.66$ hence the probability value is significant on socio-environment sustenance and development noting that sig. $=0.009$. Carefully, the researcher has rejected the null hypothesis and considered its alternate. With this in mind, community structure and dynamics has a positive influence on socio-environmental sustenance and development. Table no. 16 has shown beta $=0.478$ with the $t$ value of 4.543 as the $p$-value was 0.000 which is less than 0.05 . According to the findings, the changes in government policies, stability, and support of hydropower plant project causes the increase of $0.478(47.80 \%)$ of the socio-environment sustenance and development. The ratio of beta modal results for the $t$ value expressed $t=4.54$ hence the probability value is significant on socio-environment sustenance and development noting that sig. $=0.000$.
\end{abstract}

Key Words: hydropower plant projects, socio-environmental, sustenance, development 


\section{Introducation}

In a hydroelectric power plant, the energy of water is utilized for generating electricity which is pollutionfree and also inflation-free energy due to the absence of fuel costs. Apart from the clean and cost economic nature of power, the other key advantage includes an inherent ability for prompt starting, stopping, and load variations which helps in improving the reliability of the power system (REG, 2019).

The electricity produced from hydropower plants defines the usage of water resources towards the rise of free green energy in the absence of fuel cost with mature technology characterized by the highest prime moving efficiency and outstanding operational flexibility. Hydropower has astonishing positive social impacts, both direct and indirect. Their many multiplier effects have to be measured better and made known wider. Conventional ex-post thinking about impacts implicitly takes adverse social effects of hydropower as inevitable, virtually impossible to prevent. The consolation is that, somehow, the positive impacts outsize the negative ones, so that there is a trade-off (ESI-Africa, 2017).

A proactive approach requires pre-empting to the maximum extent possible the adverse effects from occurring, preventing them, and reducing the risks which cannot be pre-empted. There are many good practices and tried-out solutions, as the following papers in sessions show and particularly innovative experiences in China which indicate the great potential of thinking and acting differently, nonconventionally for identifying risks and overcoming the socially adverse effects.

For identifying the social impacts of the hydropower plant, it is much better to take not a piecemeal, singleplant by single-river perspective, but rather a river-basin strategic development perspective. Opportunities and needs that are less visible in a single-plant approach appear clearer when a broader river-basin horizon is embraced. The identification of social risks must logically be the first premise of any responsible consideration of the social impacts of the hydropower plant building. That requires risk prediction and analysis as part of the very concept and design of a hydropower plant building project. It also requires open and explicit discussion of risks and counters risk remedies by all stakeholders, including in this concept the project's owners, planners, implementers, the project area's inhabitants, and all the project's beneficiaries.

Developing communities face a different level of cost-benefit analysis than developed communities when it comes to large infrastructure developmental projects. Having a variety, of socioeconomic statuses within a small geographic area presents an opportunity for the disparity in impact based on environmental changes. Hydropower plants are a primary example of a large infrastructure project that presents an opportunity for economic development, while also leading to environmental changes that consequentially feedback to social and economic values of communities downstream.

Hydropower plants have the potential to produce a variety of positive and negative impacts on the surrounding people and environment. To make sure there is the maximization of the benefits of Hydropower plants in Rwanda, the valuable relationship between communities and their river networks must be done and has been done through an ESIA (Environment and Social Impact Assessment). Often limited funding, foreign investments, and time restrictions cause developers to cut corners leaving socioeconomic impact unaccounted for. With highly valued ecosystems and people who closely rely on the land for their livelihoods, it is important to take all possible impacts into account (Energy pedia 2018).

Rubagabaga hydropower plant located on the Rubagabaga River in Western Province, Rwanda. Rubagabaga hydropower plant was built in 2018 and was the first to be built on the Rubagabaga River with a capacity to feed the grid with $450 \mathrm{KwH}$, and for that reason, this power plant inarguably changed the Rubagabaga River. Like all infrastructure development, the power plant presents direct costs and benefits to the local community and country at large, while also placing externalized costs on the local communities supported by the Rubagabaga River and the surrounding environment.

According to Rwanda Energy Group (REG), Rwanda's hydropower sector showed a big development over the last decade. Currently, Rwanda's overall installed capacity is $226.7 \mathrm{MW}$ of which $48.3 \%$ is hydropower 
contributed. Involving independent power producers was a good move by the government to achieve this milestone. A favorable legal and regulatory environment for private investors in this area was equally a contribution by the government mainly through the IPPs (EUCL, 2018).

The other way was through Public-Private Partnerships whereby some government-owned hydropower plants were leased to private investors to operate and maintain. REG reports that 35 hydropower plants are grid-connected and add up to 109.712 MW and these include national and shared regional power plants. Hydropower makes up approx. $48.3 \%$ of the total installed capacity. Hydropower plants are publicly owned and operated, leased to private companies, or privately owned independent power producers. The publiclyowned power plants are managed by the national utility REG/EUCL. They include larger plants such as Ntaruka, Mukungwa, and Nyabarongo I. Independent power producers own and operate 5 plants (10 MW). Other 8 power plants $(13 \mathrm{MW})$ are privately operated through leasing agreements with the Government of Rwanda (EUCL, 2018).

It is further reported by REG that 11 micro hydropower plants MW exist in Rwanda as isolated networks. These plants were originally developed by the GoR, and handed over to private sector management to increase the private sector contribution to energy generation. GoR has recently leased out these sites to a private investor to better operate, upgrade and connect them to the grid. There are also Pico hydropower plants in the range of $1-10 \mathrm{~kW}$ which are either publicly owned or operated by the local communities or entirely private.

The country is, therefore, utilizing less than $10 \%$ of its local electricity potential, excluding a substantial solar resource, while incurring a large foreign outflow. Rwanda's electricity tariff was estimated to be about 22.2\% more expensive, compared to the highest electricity tariff of other East African Community (EAC) countries. The reports of the Electricity Access Roll-out Programme (EARP) also show that the number of new customer connections increased from 364,000 households in June 2012 to more than 700,000 households (31\% of the total households in Rwanda) in 2017.

The Rwanda government's objective targets a reliable, efficient, and affordable power supply to improve the living standards of all its population (AFDB, 2013; USAID, 2016). The electric power production capacity and electricity access are low, and the size of the infrastructure is insufficient to meet the demand. Aging infrastructure, inefficiencies, exacerbated by high technical and power losses (REG. 2017), require urgent and timely intervention to achieve the avowed energy targets (World Bank, 2017). Based on available information from REG Report, currently, $42 \%$ of the population has access to electricity: $31 \%$ gridconnected and $11 \%$ off-grid (EDCL, 2018). The electricity per capita annual consumption for half of its consumers is below $20 \mathrm{kWh}$ per month. To fulfill its mission and vision, the Rwanda Energy Group (REG) decided to: "increase generation, improve transmission, diversify energy sources, reduce costs, and produce elaborate conducive legal and regulatory frameworks" (REG, 2017).

\section{Problem Statement}

Commufnity-based hydropower plants are being explored as a viable means to harness the country's vast hydropower potential and to sustainably transition from conventional sources of energy into modern energy services and to extend the access to and availability of renewable energy to all community members with attention to vulnerable members like women (FDRE 2017). However, several obstacles may affect the longterm feasibility of community-based hydropower plants such as poor institutional capacity, lack of coordination, and inadequate implementation (Sovacool et al. 2011).

Diverse power relations within the socio-economic and environmental dimensions have negatively as well as positively affected an equal distribution of benefits from micro-energy especially in the context of the global south (Nightingale 2011). It is often assumed that electrification primarily benefits society and the environment as they are the ones who are responsible for most of the activities in place (Winther $e t$ al., 2017). This assumption potentially swells distinct differences in terms of energy needs which produces different outcomes for both aspects and are not fully reflected in energy justice (Bell, 2016).

Despite the successful electrification in Rwanda, various difficulties have been identified. For example, displacement, climate change, deforestation, are currently not compensating what they have extracted from 
the global ecosystem. The energy justice and the impacts of the electrification project, especially on indigenous, are yet to be explored. Consequently, the aim of this paper is critical to assess these regarding its contribution to energy justice directing particular attention to socio-economic and environmental impacts. The study highlights the importance of incorporating society dimensions into the energy framework and contributing to the hydropower plants projects in Rwanda.

\section{Objectives of The Study \\ General Objective}

This study investigated the effect of hydropower plant projects on socio-environmental sustenance and development in Rwanda.

\section{Specific objectives}

1. The following specific objectives were formulated to guide the study:

2. To establish the effect of Environmental assessment of hydropower plant project on socioenvironmental sustenance and development in Rwanda.

3. To investigate extend of the Community Structure and Dynamics of hydropower plant project on socio-environmental sustenance and development in Rwanda.

4. To establish the effect of Government policies, stability, and support on socio-environmental sustenance and development in Rwanda.

\section{Research Questions}

1. To what extend does Environmental assessment of hydropower plants assist in socio-environmental sustenance and development in Rwanda?

2. How do Community Structure and Dynamics of hydropower plants help in socio-environmental sustenance and development in Rwanda?

3. What is the contribution of existing government policy, stability, and support in socio-environmental sustenance and development in Rwanda?

\section{Review Of Literature \\ 5.1 Concept of variables}

\subsubsection{Hydropower plant project}

Humans have been shaping the earth's landscape since the beginning of their existence. In the same way that trees are cut down to make way for roads, hydropower plants have been built to manipulate and divert water bodies for human benefit (Bayeh, \& Endalcachew, 2015).

In this regard, developing communities face a different level of cost-benefit analysis than developed communities when it comes to large infrastructure developmental projects. Having a variety of socioeconomic statuses within a small geographic area presents an opportunity for the disparity in impact based on environmental changes (Bickerstaff, Karen, Walker, \& Bulkeley, 2013).

Most communities, from a village to a city are located adjacent to a body of water. Communities depend on rivers for basic needs until they became the next most efficient source of available power for industrial development, pulling people away from networks of navigable waters, and sprawling communities across the landscape (Cornwall, 2008; Cecelski, Elizabeth, 2006).

As global energy production shifts away from fossil fuels, and domestic production of energy is increasingly desired. Decision-makers are revisiting hydroelectric hydropower plants as a means to increase energy security and support economic growth and development (Modern hydropower, 2007).

Since hydropower is the original "fuel" of global development, looking back to the industrial revolution, it is no surprise that developing nations are increasingly turning to hydropower plants to increase domestic electricity production and distribution (Modern hydropower, 2007). 


\subsubsection{Socio-environmental sustenance and development}

The socio-environmental sustenance and development include an increase in access to public goods and services, domestic security, and energy security. Externalized costs and benefits must be weighed to determine the overall impact of a developmental project in the social and environmental realm. Where economic incentive exists; typically, social benefits exist as well. Hydropower plant projects have the potential to manipulate rivers to benefit local populations. Flood protection is an important service that allows communities to live comfortably along a river without fear of volatile flood patterns (Yuksel, 2009).

The hydropower plants provide increased water supply for arid populations and increase livelihood value (Workman, 2009). In many scenarios, they are used for hydroelectric production supports other uses such as irrigation contributing to occupations in the agricultural industry, tourism, research, and study with service development (Workman, 2009). In addition, hydropower plants have the potential to increase the navigability of waterways allowing increased river transportation of goods and services for the local people (Yuksel, 2009). In many developing nations, hydroelectric power provides electricity generation where other forms are not possible due to limited infrastructure or limited import of fossil fuels (Evans et al., 2009).

Communities are centered around rivers and other bodies of water because they rely on water as a resource. In some cases, communities could become isolated from others if river travel is the easiest and most efficient form of transportation. Isolating communities could have detrimental impacts on livelihoods by limiting trade of goods and services once depleted the groundwater or the riverbed is deepened by the project (Yuksel, 2009).

\subsubsection{Environmental assessment}

An Environmental Impact Assessment (EIA) is a systematic process used to identify, evaluate and mitigate the environmental effects of a proposed project before major decisions and commitments being made". It thus also figures as a means to ensure that projects are implemented with full awareness of environmental factors. An EIA normally results in an Environmental Management Plan (EMP) that elaborates mitigation and monitoring measures. In most industrialized countries EIAs are legally required when a proposed (hydropower) project exceeds a certain size (Barros, et al. 2011).

\subsubsection{Community Structure and Dynamics}

Understanding community structure and dynamics enable community ecologists to manage ecosystems more effectively. Foundation species may physically modify the environment to produce and maintain habitats that benefit the other organisms that use them. Community dynamics are the changes in community structure and composition over time. Sometimes these changes are induced by environmental disturbances such as volcanoes, earthquakes, storms, fires, and climate change. Communities with a stable structure are said to be at equilibrium. Following a disturbance, the community may or may not return to the equilibrium state. Succession describes the sequential appearance and disappearance of species in a community over time. In primary succession, newly exposed or newly formed land is colonized by living things; in secondary succession, part of an ecosystem is disturbed and remnants of the previous community remain (Agarwal \& Bina, 2001).

\subsubsection{Governmental policies, stability, and support}

The Guideline aims to provide policy guidance to the agencies responsible for overseeing the implementation of investment projects in the hydropower sector as well as to inform and encourage project developers/investors to be aware of the Government policy toward achieving sustainable development. One of the challenges in creating public-private partnerships is for governments to create an appropriate environment to attract private investment. When governments implement policy decisions and resolve political conflicts through the legislative and regulatory process, their role is objectively to carry out the will of the body politic (Barros, et al., 2011).

\subsection{Theoretical Review}




\subsubsection{Sustainable Development theory}

Hydropower and Sustainable Development is broadly discussed topic. There are two dominant views when it comes to hydropower and its role in Sustainable Development. International River Network (IRN 2004) on the one hand states that "the technology can only play a role in sustainable energy development if its planning and management are subject to strict guidelines and criteria, alternatives are fully considered and projects are implemented through transparent and accountable processes". This perspective has led several financing organizations to develop guidelines and criteria for hydro facilities, with the most famous being the World Commission on Dams report in 1998. European Small-Hydropower Association (2004), on the other hand, describes very hauntingly the general view of most project developers concerning impacts on the environment, regarding the fact, that the production of hydroelectricity does not emit polluting substances, electricity from a hydropower plant could be considered as clean. What can be added is that special care has to be taken to limit the local environmental impacts of the turbine setting and operations on the ecosystem where the turbine acts.

\subsubsection{Neoclassical sustainability of the growth Theory}

The neoclassical theory of growth (or development) considers the increase of production and, therefore, of disposable income in higher levels of consumption as a solution to poverty for progress and development. The neoclassical approach is based on the assumption that the capacity for self-regulation (Tietenberg, 2006) of free markets and not bound, and technological advances can ensure the capacity of substitutions endless between the various forms of capital, mitigating so, the constraints arising from the possible scarcity of resources, allow sustainable growth, a level of consumption does not decrease over time. The rule provides that if royalty or user cost (Tietenberg, 2006) generated by the extraction, according to an efficient plan, of non-renewable resources are fully saved and reinvested in renewable capital, the level of resulting investment would be sufficient to provide a value of the capital stock (economic) at least constant over time, making it possible product levels and consumption of non-decreasing (i.e: the sustainability of development). Thus becomes almost irrelevant the fact that is limited the availability of natural resources also non-renewable. Consumption levels may remain non-decreasing with exhaustible resources that decrease (Musu., 2003), if you do so that the capital stock remains unchanged at least, guaranteeing in any period an adequate investment in man-made capital.

\subsection{Empirical Review}

\subsubsection{Environmental assessment and Socio-Environmental Sustenance \& Development}

Local people usually have more experiences of neighboring areas as they use them more than others and are therefore assumed to develop a stronger attachment to the areas. Thus, their opposition to environmental change is expected to be greater than those with weaker place attachments. This relationship has been studied empirically and evaluated the connections between place attachment and the local opposition against a proposed hydropower plant project in an area. It was shown that the stronger local people felt attached to the proposed area the more positive they were towards development, indicating that a power plant in the area would increase the place attachment (AFDB, 2013).

On the other side of the fence is the Ministry of Infrastructure which has to provide more citizens with access to electricity and deliver a stable supply of energy to businesses. To date, only $46 \%$ of Rwandans have electricity. There are however frequent power cuts that affect the production and competitiveness of companies, particularly in the north and in rural areas. It is hard to avoid the impression that the government is too hasty in collaborating with private foreign investors. In recent years, the intervention in bidding processes on several occasions. It deemed the pace of progress of these large-scale projects too slow. The notorious tardiness of the authorities responsible for the drawing-up and granting of the necessary environmental and social impact assessments encourage many bidders to circumvent the requirements. This undermines the trust of all concerned in achieving a fair solution (Beaty, 2000). Regarding environmental impacts, according to the village leaders and cooperative members, the plants do not have many negative impacts on the environment. Quite the contrary, it is reported that the reduced rates of deforestation after electrification of the villages. Environmental problems such as landslides and sedimentation occur instead due to population growth and agricultural expansion that are pushed by hydropower construction (Meder, 2011). 
More so, problems of displacement caused by global hydropower development and proposes a new solution that incorporates national and international accountability and provides more protection of the human rights of displaced persons. The current trend of involuntary displacement for hydropower development projects with specific examples from three countries depicts how nations vary in displacement practices but are nonetheless all unfair to indigenous populations, leading to global human rights violations. It is proposed as a global solution to this involuntary displacement problem by involving both national and transnational actors. Nations should, by law, protect their populations from government takings and provide them with opportunities for effective participation and adequate reimbursement (Bailey, 2014).

\subsubsection{Community Structure \& Dynamics and Socio-Environmental Sustenance \& Development}

In reality, the performance of a hydro-power plant is mainly determined by the parameters of the water that has been directed to the turbine. According to Singh \& al. (2011), some of these parameters include the effects of water inertia, water compressibility, and pipe wall elasticity in the penstock. The effect of water inertia is to ensure that changes in turbine flow do normally lag behind changes in turbine gate opening for a smooth operation. On the other hand, the effect of elasticity introduces some elements of pressure and flow in the pipe, a phenomenon known as water hammer. Other parameters of the flowing water also affect the flow of water and indirectly affect the turbine speed which is directly connected to the generator. To have constant power generation it is, therefore, necessary to implement strong control measures to overcome the variability of the initial flowing water (Singh \& al. 2011). Today, the debate about the social liabilities of hydropower development revolves around population displacement and forced resettlement. These are grave issues indeed. Yet, they are not intractable. Three elements explain why displacement processes have overtaken much of the debate around hydropower plants, both in developing countries and developed ones. First, the magnitude of human impacts that is large groups of people is adversely affected, profoundly and enduringly, by imposed material losses and social disruptions. Second, absent, or weak regulation frameworks reflected as policies and laws for socially responsible resettlement are still missing now, at the start of the 21st century, in most developing countries. Human rights violations bedevil most displacements. Third, under-financing that incorporates classic economic theory regards cost externalization as an unsound and unacceptable practice (Asemota, \& Li, 2018).

\subsubsection{Governmental policies, stability \& support and Hydropower Projects}

Areas, where it may be appropriate for the government to play a role, include national energy planning; resource evaluation; market evaluation; least-cost-planning; providing access to expertise; eliminating obstacles to equitable markets; project oversight and evaluation; and assistance in providing access to capital and financing (Alam, 2013).

One of the challenges in creating public-private partnerships is for governments to create an appropriate environment to attract private investment. When governments act in their sovereign role as guardians of the public welfare, they are essentially providers of public goods and services, which in turn may be delivered through public or private channels. When governments implement policy decisions and resolve political conflicts through the legislative and regulatory process, their role is objectively to carry out the will of the body politic (McCauley et al., 2013). In addition, to technological efforts, government intervention in hydropower management and regulation should not be ignored. National, regional, and local governments can establish effective measures to promote the implementation of hydropower and other renewable energy projects, to regulate and govern hydropower electricity utilization, to assist managers with flood-control operations during high flow episodes and improve water usage procedures during drought periods, and, ensure the safety of environmental, eco-system, and socio-economic sectors (Gross, Catherine, 2007).

\subsection{Conceptual Framework}

Figure 1: Figure identifying the variables of the research.

Hydropower Projects

\section{Socio-Environmental Sustenance}

\section{and Development}

Environmental assessment

Dr. MUTESI Jean Claude, IJSRM Volume10 Is
- Public Acceptance to Change

Infrastructure development and job creation

Access to Electricity Resources and Electricity Quality

Tourism 
Community Structure and Dynamics

Governmental policies, stability, and

Source: Researcher (2021)

\section{Materials And Methods}

This study was descriptive because it describes the socio-economic and environmental impacts and hydropower in Nyabihu District. Moreover, the researcher used descriptive design because this study intends to explore the relationship between variables studied.

\section{Target population}

The target population of this study was a total number of 252 households including people from villages immediately neighboring the plant in the sector in Nyabihu District.

Sample size and sampling procedures A sample was a smaller set of standards designated from the determination of the sample size of this research was indicated as 154 based on Solvins' formula as stated below and declares that for a population of 252 individuals or households, the sample can be 152 as sample size. The sample size was 154 as the total sample made of people from the local community with a close relationship with the Rubagabaga hydropower plant project located in the District. Given: $\mathrm{n}=$ Sample size; $\mathrm{N}=$ Study population; $\mathrm{e}=$ margin of error which determined based on the confidence level (expressed in percentages). For this study, the sample is calculated as follows:

$\mathbf{N}=252$; Confidence level $=95 \%$ thus, $\mathrm{e}=0.05$.

$\mathbf{n}=\mathrm{N} /\left(1+\mathrm{N}(0.05)^{\wedge} 2\right)$. Then, $\mathbf{n}=252 /\left(1+252(0.05)^{\wedge} 2\right)=154$.

In this study, simple random sampling is applied to all villages surrounding the hydropower plant.

\section{Data Collection Instrument Questionnaire technique}

Majority of the questions were multiple-choice, closed-ended questions based on a five-point Likert scale that are namely $1=$ strongly disagree, $2=$ disagree, $3=$ neutral, $4=$ agree, $5=$ strongly agree. Certain means were calculated from the results to make a comparison between different aspects possible. The questionnaires are mode of closed questions and were distributed to the respondents who are of course able to answer these questions that finally serve to get rich data enabling the researcher to properly achieve the objectives. This method helped the researcher to save time because in a short time all the informants had finished responding, hence the sufficient time to the researcher for data preparation

\section{Data Analysis Methods}

The collected raw data was inspected to ensure it is complete and accurate. Questionnaires were organized and classified according to the study objectives. Qualitative data were classified and coded into themes and concepts for analysis based on the objectives of the study. This study employed Karl Pearson's coefficient of correlation. Karl Pearson's coefficient of correlation is a method that was used for measuring the degree of relationship between two variables. Since the symbol used to identify Pearson's Correlation Coefficient is a lower case "r", it is often called "Pearson's r". This coefficient assumes that there is a linear relationship between the two variables that the two variables are causally related which means that one of the variables is independent and the other one is dependent, and a large number of independent causes are operating in both variables to produce a normal distribution.

\section{Description of Descriptive statistics}

The mean is the balance point of the data or the measure of the center of a distribution of a quantitative variable (Freanckel \& Wallen, 2006). The researcher evaluated the mean by using these equivalences which are found in the table. These equivalences of mean helped to know the perception of each group about the sub-variables.

\section{Correlation Analysis}


Pearson correlation coefficient is a statistical measure of the strength of a monotonic relationship between paired data. In a sample it is denoted by and is by $\mathbf{r}_{\mathrm{s}}$ design constrained as follows: $\mathbf{- 1} \leq \mathbf{r}_{\mathrm{s}} \leq \mathbf{1}$

\section{Khi-Square Test}

The model that used in this study is the Khi-square test distribution, this facilitated to verification of the possible relationship between two categorical variables. Its symbol is "x squared" $\left(\mathrm{x}^{2}\right)$. This is a commonly used statistical procedure. The Khi-Square statistic appears as an option when requesting a cross-tabulation in SPSS.

The output is labeled Khi-Square Tests; the Khi-Square statistic used in the Test of Independence was labeled Pearson Khi-Square. This statistic can be evaluated by comparing the actual value against a critical value found in a Khi-Square distribution. Khi-Square allows the researcher to answer important questions with variables measured with nominal or ordinal scales. The calculation of Khi-square statistics was given as follow:

$$
\chi^{2}=\sum \frac{\left(f_{0}-f_{e}\right)^{2}}{f_{e}}
$$

Where: $\boldsymbol{f}_{\mathrm{o}}=$ the observed frequency (the observed counts in the cells), and $f \mathrm{e}=$ the expected frequency if no relationship existed between the variables. A Khi-square test gives a p-value. The p-value tells if test results are significant or not. To perform a Chi-square test and get the p-value, you need two pieces of information: degrees of freedom. That's just the number of categories minus 1.

The alpha level $(\alpha)$. This is chosen by the researcher. The usual alpha level was $0.05(5 \%)$, to conclude the hypothesis with 95\% confidence, the value labeled Asymp. Sig. (which is the p-value of the Khi-Square statistic) should be less than 0.05 (which is the alpha level associated with a 95\% confidence level).

\section{Regression analysis}

Regression analysis is a set of statistical methods used for the estimation of relationships between a dependent variable and one or more independent variables. It was utilized to assess the strength of the relationship

\section{Results and Discussions of Findings}

Supportively, the study has worked on specific objectives establishing the effects of environmental assessment of hydropower plant project, the extend of community structure and dynamics of hydropower plant project, the effect of government policies, stability, and support on socio-environment sustenance and development in Rwanda. The data obtained from the field has been presented in form of quantitative which allowed us to give accurate explanations of the findings in general. Using descriptive statistics was helpful in terms of simplifying a large amount of data easily and sensibly. It is very easy to summarize the data and consider a small number of variables and data which easy the interpretation.

\subsection{Findings in Regression analysis}

7.1.1 Testing objective one: the effect of Environmental assessment of hydropower plant project on socioenvironmental sustenance and development in Rwanda.

Table 1: ANOVA table for the relationship between Environmental assessment of hydropower plant project on socio-environmental sustenance and development

\begin{tabular}{|l|l|c|c|c|c|c|}
\hline \multicolumn{7}{|c|}{ ANOVA } \\
\hline \multicolumn{2}{|l|}{ Model } & Sum of Squares & df & Mean Square & F & Sig. \\
\hline \multirow{2}{*}{1} & Regression & .781 & 4 & .195 & 3.423 & $.011^{\mathrm{b}}$ \\
\cline { 2 - 7 } & Residual & 7.876 & 138 & .057 & & \\
\cline { 2 - 7 } & Total & 8.657 & 142 & & & \\
\hline
\end{tabular}

Source: Field data (2021)

ANOVA table No1 provided summarized information for the effect of environmental assessment on socialenvironmental sustenance and development in Rwanda. The regression equation shows how that the data are fit and predict the changes happening to the dependent and independent variables through a statistical 
significance the $p$-value equivalent to 0.11 which is under 0.05 . Meaning that $p<0.05$. To wind up, the regression model is observed as statistically strong and the variables are significant.

Table 2: Model summary table of the relationship between Environmental assessment of hydropower plant project on socio-environmental sustenance and development

\begin{tabular}{|l|r|rr|r|r|}
\hline \multicolumn{9}{|c|}{ Model Summary } \\
\hline Model & R & \multicolumn{2}{|c|}{ R Square } & Adjusted R Square & $\begin{array}{c}\text { Std. Error of the } \\
\text { Estimate }\end{array}$ \\
\hline 1 & & $.300^{\mathrm{a}}$ & \multicolumn{2}{|c|}{. } & \multicolumn{2}{|c|}{.090} & .064 & .23890 \\
\hline
\end{tabular}

Source: Field data (2021)

Usually, the R-value indicated the rate at which two variables correlated which is supported by the R square indicating the total variation between the variables. The R-value was estimated to be 0.300 indicating a positive relationship between the variables. The R square demonstrated a value of 0.09 or estimated to $9 \%$ indicating the total variation at which environmental assessment of hydropower project and socioenvironmental sustenance and development affect each other. All in all, there is a relationship existing between environmental assessment of hydro plant project and socio-environmental sustenance and development, and the relationship can be explained.

7.1.2 Testing objective two: the extend of Community Structure and Dynamics of hydropower plant project on socio-environmental sustenance and development in Rwanda

Table 3: ANOVA table of the relationship between Community Structure of hydropower plant project on socio-environmental sustenance and development

\begin{tabular}{|l|l|c|c|c|c|c|}
\hline \multicolumn{2}{|c|}{ Model } & $\begin{array}{c}\text { Sum of } \\
\text { Squares }\end{array}$ & Df & Mean Square & F & Sig. \\
\hline \multirow{2}{*}{1} & Regression & .468 & 5 & .094 & 5.190 & $.000^{\mathrm{b}}$ \\
\cline { 2 - 7 } & Residual & 2.469 & 137 & .018 & & \\
\cline { 2 - 7 } & Total & 2.937 & 142 & & & \\
\hline
\end{tabular}

Source: Field data (2021)

The ANOVA table No3 provided summarized information for the extent of community structure and dynamics of hydropower plant projects on social-environmental sustenance and development in Rwanda. The regression equation shows how that the data are fit and predict the changes happening to the dependent and independent variables through a statistical significance the p-value equivalent to 0.000 which is under 0.05 . Meaning that $p<0.05$. Hitting the point, the regression model is observed as statistically strong and the variables are significant.

Table 4: Model summary table of the relationship between Community Structure of hydropower plant project on socio-environmental sustenance and development

\begin{tabular}{|l|r|r|r|r|}
\hline \multicolumn{6}{|c|}{ Model Summary } \\
\hline Model & R & R Square & Adjusted R Square & $\begin{array}{c}\text { Std. Error of the } \\
\text { Estimate }\end{array}$ \\
\hline 1 & $.399^{\mathrm{a}}$ & \multicolumn{2}{|c|}{.159 } & .129 \\
\hline
\end{tabular}

Source: Field data (2021)

As per table No4, the model summary shows how the community structure of the hydropower plant project affects the socio-environmental sustenance and development. The data demonstrated the proofs for the second objective of this study. Two important values that are $\mathrm{R}$ and $\mathrm{R}$ square demonstrated the rates at which the relationship between two variables is established. Usually, the R-value indicated the rate at which two variables correlated which is supported by the $\mathrm{R}$ square indicating the total variation between the variables. The R-value was estimated to be 0.399 indicating a positive relationship between the variables. The R square demonstrated a value of 0.159 or estimated to be $15.9 \%$ indicating the total variation at which community structure of hydropower project and socio-environmental sustenance and development affect each other. In a nutshell, there is a relationship existing between the Community structure of the hydropower plant project and socio-environmental sustenance and development, and the relationship can be explained. 
7.1.3 Testing objective three: the effect of Government policies, stability, and support on socioenvironmental sustenance and development in Rwanda

Table 5: ANOVA table of the relationship between Government policies, stability, and support of hydropower plant project on socio-environmental sustenance and development

\begin{tabular}{|l|l|r|r|r|r|r|}
\hline \multicolumn{2}{|l|}{ ANOVA } \\
\hline \multirow{2}{*}{ Model } & $\begin{array}{c}\text { Sum of } \\
\text { Squares }\end{array}$ & \multicolumn{1}{c|}{ Df } & $\begin{array}{c}\text { Mean } \\
\text { Square }\end{array}$ & \multicolumn{1}{c|}{ F } & Sig. \\
\hline \multirow{3}{*}{1} & Regression & .479 & 3 & .160 & 14.880 & $.000^{\mathrm{b}}$ \\
\cline { 2 - 8 } & Residual & 1.493 & 139 & .011 & & \\
\cline { 2 - 8 } & Total & 1.972 & 142 & & & \\
\hline
\end{tabular}

Source: Field data (2021)

The awareness of the environment goes back to the past as the action is taken only aimed at protecting and conservation of the environment under active circumstances and political benefits. The ANOVA table No5 provided summarized information for the effect of Government policies, stability, and support on socialenvironmental sustenance and development in Rwanda. The regression equation shows how that the data are fit and predict the changes happening to the dependent and independent variables through a statistical significance the $\mathrm{p}$-value equivalent to 0.000 which is under 0.05 . Meaning that $\mathrm{p}<0.05$. To wind up, the regression model is observed as statistically strong and the variables are significant.

Table 6: Model summary table of the relationship between Government policies, stability, and support of hydropower plant project on socio-environmental sustenance and development

\begin{tabular}{|c|c|c|c|c|}
\hline \multicolumn{5}{|c|}{ Model Summary } \\
\hline Model & $\mathbf{R}$ & R Square & Adjusted R Square & $\begin{array}{l}\text { Std. Error of the } \\
\text { Estimate }\end{array}$ \\
\hline 1 & $.493^{\mathrm{a}}$ & .243 & .227 & .10363 \\
\hline
\end{tabular}

Source: Field data (2021)

Interpreting table No6, the model summary shows how government policies, stability, and support of hydropower plant projects affect the socio-environmental sustenance and development. The data demonstrated the proofs for the third objective of this study. Two important values that are $\mathrm{R}$ and $\mathrm{R}$ square demonstrated the rates at which the relationship between two variables is established. Usually, the R-value indicated the rate at which two variables correlated which is supported by the $\mathrm{R}$ square indicating the total variation between the variables. The R-value was estimated to be 0.493 indicating a positive relationship between the variables. The $\mathrm{R}$ square demonstrated a value of 0.243 or estimated to be $24.3 \%$ indicating the total variation at which government policies, stability, and support of hydropower plant projects and socioenvironmental sustenance and development affect each other. Briefly, there is a relationship existing between Government policies, stability and support of hydropower plant projects, and socio-environmental sustenance and development, and the relationship can be explained.

\subsection{Predicting the Effect of Objectives}

Table 7: Coefficient of hydropower plant projects on socio-environmental sustenance and development

\begin{tabular}{|c|c|c|c|c|c|c|}
\hline \multicolumn{7}{|c|}{ Coefficients } \\
\hline \multirow{2}{*}{\multicolumn{2}{|c|}{ Model }} & \multicolumn{2}{|c|}{$\begin{array}{l}\text { Unstandardized } \\
\text { Coefficients }\end{array}$} & \multirow{3}{*}{$\begin{array}{c}\begin{array}{c}\text { Standardized } \\
\text { Coefficients }\end{array} \\
\text { Beta } \\
.397 \\
\end{array}$} & \multirow{3}{*}{$\frac{\mathbf{t}}{2.333}$} & \multirow{3}{*}{$\begin{array}{l}\text { Sig. } \\
.021\end{array}$} \\
\hline & & \multirow{2}{*}{$\begin{array}{c}\text { B } \\
3.012 \\
\end{array}$} & \multirow{2}{*}{$\begin{array}{c}\text { Std. Error } \\
1.291 \\
\end{array}$} & & & \\
\hline 1 & Environmental assessment & & & & & \\
\hline 2 & \begin{tabular}{|lll}
$\begin{array}{l}\text { Community } \\
\text { Dynamics }\end{array}$ & Structure and \\
\end{tabular} & 2.843 & 1.066 & .341 & 2.668 & .009 \\
\hline 3 & $\begin{array}{l}\text { Government policies, stability, } \\
\text { and support }\end{array}$ & 2.590 & .570 & .478 & 4.543 & .000 \\
\hline
\end{tabular}

Source: Field data (2021) 
Table No7 above showed that beta is 0.397 with the $\mathrm{t}$-value of 2.333 as the p-value was 0.021 . The p-value is less than 0.05. Therefore, we rejected the null hypothesis and considered it alternate. There is a strong positive relationship between environmental assessment of hydropower plant projects and socioenvironmental sustenance and development. The beta is also equal to 0.341 with the $t$ value of 2.668 as the $p$ value was 0.009 . The $\mathrm{p}$-value is less than 0.05 . Therefore, we rejected the null hypothesis and considered it alternate. There is a strong positive relationship between the community structure of the hydropower plant project and socio-environmental sustenance and development. The table above shows beta $=0.478$ with the $t$ value of 4.543 as the p-value was 0.000 . The p-value is less than 0.05 . Therefore, we rejected the null hypothesis and considered it alternate. There is a strong positive relationship between government policies, stability, and support on socio-environmental sustenance and development

\subsection{Chi-square test}

Chi-square test of Environmental assessment

Table 8: Chi-square test of Environmental assessment

\begin{tabular}{|l|c|c|c|c|c|}
\hline \multicolumn{7}{|c|}{ Chi-Square Tests } \\
\hline & Value & df & $\begin{array}{c}\text { Asymp. Sig. } \\
\text { (2-sided) }\end{array}$ & $\begin{array}{c}\text { Exact Sig. } \\
\text { (2-sided) }\end{array}$ & $\begin{array}{c}\text { Exact Sig. } \\
\text { (1-sided) }\end{array}$ \\
\hline Pearson Chi-Square & $.043^{\mathrm{a}}$ & 1 & .835 & & \\
\hline Continuity Correction & .000 & 1 & 1.000 & & \\
\hline Likelihood Ratio & .085 & 1 & .770 & & \\
\hline Fisher's Exact Test & & & & 1.000 & .958 \\
\hline Linear-by-Linear Association & .043 & 1 & .835 & & \\
\hline
\end{tabular}

Source: Field data (2021)

As per table No8, the chi-square test for the environmental assessment is presented. The test indicated the asymptotic sig. value (2-sided) which has shown the Pearson value for the environmental assessment estimated at 0.835 . This $\mathrm{p}$-value demonstrated that the $\mathrm{p}$-value exhibited a high strong and positive relationship linking two variables. Therefore, environmental assessment contributes to the improvement of socio-environmental sustenance and development in Rwanda.

\section{Chi-square test of Community Structure and Dynamics}

Table 9: Chi-square test of Community Structure and Dynamics

\begin{tabular}{|l|c|c|c|c|c|}
\hline \multicolumn{7}{|c|}{ Chi-Square Tests } \\
\hline & Value & df & $\begin{array}{c}\text { Asymp. } \\
\text { Sig. } \\
\text { (2-sided) }\end{array}$ & $\begin{array}{c}\text { Exact Sig. } \\
\text { (2-sided) }\end{array}$ & $\begin{array}{c}\text { Exact Sig. } \\
\text { (1-sided) }\end{array}$ \\
\hline Pearson Chi-Square & $.029^{\mathrm{a}}$ & 1 & .865 & & \\
\hline Continuity Correction & .000 & 1 & 1.000 & & \\
\hline Likelihood Ratio & .057 & 1 & .812 & & \\
\hline Fisher's Exact Test & & & & 1.000 & .972 \\
\hline Linear-by-Linear Association & .029 & 1 & .866 & & \\
\hline
\end{tabular}

Source: Field data (2021)

According to table No9, the chi-square test for the community structure is projected. The test indicated the asymptotic sig. value (2-sided) which has shown the Pearson value for the environmental assessment estimated at 0.865 . This $\mathrm{p}$-value demonstrated that the $\mathrm{p}$-value has shown that there is a positive and strong relationship linking two variables. Therefore, community structure contributes to the improvement of socioenvironmental sustenance and development in Rwanda

Chi-square test of Government policies, stability, and support

Table 10: Chi-square test of Government policies, stability, and support

\begin{tabular}{|c|c|c|c|c|c|}
\hline \multicolumn{7}{|c|}{ Chi-Square Tests } \\
\hline & Value & df & $\begin{array}{c}\text { Asymp. Sig. (2- } \\
\text { sided) }\end{array}$ & $\begin{array}{c}\text { Exact Sig. (2- } \\
\text { sided) }\end{array}$ & $\begin{array}{c}\text { Exact Sig. (1- } \\
\text { sided) }\end{array}$ \\
\hline
\end{tabular}




\begin{tabular}{|l|r|r|r|r|r|}
\hline Pearson Chi-Square & $.043^{\mathrm{a}}$ & 1 & .835 & & \\
\hline Continuity Correction & .000 & 1 & 1.000 & & \\
\hline Likelihood Ratio & .085 & 1 & .770 & & \\
\hline Fisher's Exact Test & & & & 1.000 & .958 \\
\hline $\begin{array}{l}\text { Linear-by-Linear } \\
\text { Association }\end{array}$ & .043 & 1 & .835 & & \\
\hline
\end{tabular}

Source: Field data (2021)

As per table No10, the chi-square test for the government policies, stability, and support is presented. The test indicated the asymptotic sig. value (2-sided) which has shown the p-value or Pearson value for the environmental assessment estimated at 0.835 . This p-value demonstrated that there is a high and positive relationship linking two variables. In closing, environmental assessment contributes to the improvement of socio-environmental sustenance and development in Rwanda.

\subsection{Correlation analysis}

Table 11: Correlation matrix of hydropower plant projects on socio-environmental sustenance and development

\begin{tabular}{|l|c|c|c|c|}
\hline & $\begin{array}{c}\text { Socio- } \\
\text { environmental } \\
\text { sustenance and } \\
\text { development }\end{array}$ & $\begin{array}{c}\text { Environmenta } \\
\text { I assessment }\end{array}$ & $\begin{array}{c}\text { Community } \\
\text { Structure and } \\
\text { Dynamics }\end{array}$ & $\begin{array}{c}\text { Government } \\
\text { policies, } \\
\text { stability, and } \\
\text { support }\end{array}$ \\
\hline $\begin{array}{l}\text { Socio-environmental } \\
\text { sustenance and } \\
\text { development }\end{array}$ & 1 & & & \\
\hline Environmental assessment & $.533^{* *}$ & 1 & & \\
\hline $\begin{array}{l}\text { Community Structure and } \\
\text { Dynamics }\end{array}$ & $.493^{* *}$ & $.272^{* *}$ & 1 & \\
\hline $\begin{array}{l}\text { Government policies, } \\
\text { stability and support }\end{array}$ & $.398^{* *}$ & $.254^{* *}$ & $.208^{*}$ & \\
\hline $\begin{array}{l}* \text { Correlation is significant at } 0.5 \text { level (2-tailed) } \\
* * \text { Correlation is significant at } 0.01 \text { level (2-tailed) }\end{array}$ & & & \\
\hline
\end{tabular}

Source: Field data (2021)

As a simple interpretation from the table per No11, the correlation exists between Environmental assessment and socio-environmental sustenance and development in Rwanda it was measured at $0.533^{* *}$. This value shown from the table above signifies how strong the relationship between the variables is as it is a positive degree to which Environmental assessment and socio-environmental sustenance and development. We noticed that the p-value was 0.000 (2-tailed) which also supports the fact that there is a strong and positive linear connection between the two variables tested in this study. Moving forward, the researcher has accepted the hypothesis above by saying that Environmental assessment has a significant positive effect on the success of socio-environmental sustenance and development.

Studying the table as per no11, the correlation exists between Community Structure and Dynamics and the successfulness of socio-environmental sustenance and development was measured at $0.493 * *$. This value shown from the table above signifies how strong the relationship between the variables is as it is a positive degree to which Community Structure and Dynamics and socio-environmental sustenance and development. Additionally, we noticed that the p-value was 0.000 (2-tailed) which also supports the fact that there is a strong and positive linear relationship between the two variables tested in this study. In closing, the researcher has accepted the hypothesis above by saying that Community Structure and Dynamics have a significant effect on socio-environmental sustenance and development.

Looking over the table per no11, the correlation between Government policies, stability and support, and socio-environmental sustenance and development in Rwanda were found to be at $0.398^{* *}$. This value shown from the table above demonstrates how strong the relationship between the variables is as it is a positive degree to which Government policies, stability and support, and successfulness of socio-environmental sustenance and development. We noticed that the p-value was 0.000 (2-tailed) which also supports the fact 
that there is a strong and positive linear connection between the two variables tested during the research. To sum up, the researcher has accepted the hypothesis above by saying that Government policies, stability, and support have a significant effect on socio-environmental sustenance and development in Rwanda.

\section{Conclusion and Recommendations}

Due to the remarkable role that hydropower plants have demonstrated in boosting the social standards of people, there is a need to input continuous efforts for both private and public sectors and encourage the individual to take care of the existing energy. There is a need in encouraging projects proposals reflecting on environmental assessment and projects funding strategies should be renewed. Although a higher percentage of sources that product hydropower and other related power have already been discussed, a small percentage need to be discovered and this can be applied once the initiative in exploring the availability of energy expansion and proposals can be a great start. One of the most important purposes that proposals contribute to the decision-makers includes easily projected outcomes.

Depending on past experiences, different types of and sources of hydropower-based energy including watersheds, rivers, and electric power plants which have been discovered but which all abide by the projects proposed form individuals and organizations in general. Both public and private institutions should work toward improving the level of technology that is used in producing hydropower-based energy

\section{References}

1. Abbasi, T. (2011). Small hydro and the environmental implications of its extensive utilization. Renewable and Sustainable Energy Reviews 15, p 2134-2143.

2. Abrate, T. (1999). Water availability and data availability. WMO policy and activity, in Anne,

3. Abson, D. \& Termansen, M. (2011). Valuing ecosystem services in terms of ecological risks and returns. Conservation Biology, 25, p250-258.

4. AFDB (2013a). Rwanda Energy Sector: Review and Action Plan.

5. AFDB (2013b). Rwanda-Scaling up Energy Access Project.

6. Agarwal, \& Bina. (2001). Participatory Exclusions, Community Forestry, and Gender: An Analysis for South Asia and a Conceptual Framework." World Development 29 (10): 1623-1648.

7. Agrawala, S., Raksakulthai, V., van Aalst, M., Larsen, P., Smith, J. \& Reynolds, J. (2003). Development and climate change in Nepal: Focus on water resources and hydropower. Paris: Environment Directorate, Development Co-Operation Directorate of Nepal, Organisation for Economic Co-operation and Development.

8. Alam, S. (2013). Sediment data collection over a long-term period: essential for better sediment management at hydro projects. Addis Ababa: The International Journal on Hydropower and Dams.

9. Alavian, V., Qaddumi, H. M., Dickson, E., Diez, S. M., Danilenko, A. V., Hirji, R. F., ... \& Blankespoor, B. (2009). Water and climate change: understanding the risks and making climate-smart investment decisions. Washington, DC: World Bank, 52911.

10. Arias, M., Cochrane, T., Lawrence, K., Killeen, T. \& Farrell, T. (2011). Paying the forest for electricity: A modeling framework to market forest conservation as payment for ecosystem services benefiting hydropower generation, Environmental Conservation, Volume 38, Issue 4.

11. Arnell, N. (1996). Global warming, river flows, and water resources. Chichester, UK: Wiley.

12. Baanabe, J. (2008). Large scale hydropower, renewable energy adaptation and climate change, and energy security in the East and Horn of Africa. HBF.

13. Bacon, R., Besant-Jones, J. \& Heirarian, J. (1996). Estimating construction costs and schedules: experience with power generation projects in developing countries. Technical Paper 325 . Washington, D. C.: World Bank.

14. Bailey, P. (2014). Leisure and Class in Victorian England: Rational Recreation and the contest for control, 1830-1885. Routledge.

15. Barry, M. L., Steyn, H., and Brent, A. (2011). Selection of renewable energy technologies for Africa: eight case studies in Rwanda, Tanzania, and Malawi. Renew. Ener. 36, 2845-2852. DOI: 10.1016/j.renene.2011.04.016

16. Bartle, A. (2002). Hydropower potential and development activities', Energy Policy 30, p1231-1239. 
17. Bayeh, \& Endalcachew. (2015). Human Rights in Ethiopia: An Assessment on the Law and Practice of Women's Rights. Humanities and Social Sciences 3 (2): 83-87.

18. Bayeh, Endalcachew. (2016). The Role of Empowering Women and Achieving Gender Equality to the Sustainable Development of Ethiopia. Pacific Science Review B: Humanities and Social Sciences 2 (1): $37-42$.

19. Beaty, H. W. (2000). Electrochemistry and Electrometallurgy, in Standard Handbook for Electrical Engineers, 14th and., eds G. D. Fink, and H. W. Beaty (McGraw-Hill), 24-2-24-38.

20. Becker, G. S. (1994). Human capital revisited. In Human Capital: A Theoretical and Empirical Analysis with Special Reference to Education, Third Edition (pp. 15-28). The University of Chicago Press.

21. Bensch, G., Kluve, J., \& Peters, J. (2011). Impacts of rural electrification in Rwanda. J. Dev. Effect. 3, 567-588. DOI: 10.1080/19439342.2011.621025

22. Bernard, J. T. (1989). A Ricardian theory of hydroelectric power development: some Canadian evidence. Canadian Journal of Economics, 328-339.

23. Bickerstaff, Karen, Walker, \& Bulkeley, H. (2013). Energy Justice in a Changing Climate: Social Equity and Low-Carbon Energy. London: Zed Books Ltd.

24. Bimenyimana, S., Asemota, G. N., \& Li, L. (2018). The state of the power sector in Rwanda: a progressive sector with ambitious targets. Frontiers in Energy Research, 6, 68.

25. Brew-Hammond, A. (2010). Energy access in Africa: challenges ahead. Energy Policy 38, 22912301. DOI: 10.1016/j.enpol.2009.12.016 CR (Construction Review Online) (2017). Rwanda Launches First Peat-Fired

26. Brokensha, D. \& Scudder, T. (1968). Hydropower plants in Africa: An Interdisciplinary Study of Man-made Lakes in Africa. (pp. 20-62). London: Frank Cass and Company Limited.

27. Cecelski, E. (2006). From the Millennium Development Goals towards a gender-sensitive energy policy research and practice: Empirical evidence and case studies. Collaborative Research Group on Gender and Energy, Netherlands.

28. Cernea, M. M. (1997). The risks and reconstruction model for resettling displaced populations. World Development, 25(10), 1569-1587.

29. Cernea, M. M. (2000). Risks, safeguards, and reconstruction: A model for population displacement and resettlement. Economic and Political Weekly, 3659-3678.

30. Cernea, M. M. (2003). For new economics of resettlement: a sociological critique of the compensation principle. International social science journal, 55(175), 37-45.

31. Chirenje, Leonard I., Richard A. Giliba, and Emmanuel B. \& Musamba. (2013). Local Communities' Participation in Decision-Making Processes through Planning and Budgeting in African Countries. Chinese Journal of Population Resources and Environment 11 (1): 10-16.

32. Clancy, Joy, S., Tanja Winther, Margaret Njirambo Matinga, \& Oparaocha, S. (2011). Gender Equity in Access to and Benefits from Modern Energy and Improved Energy technologies. World Development Report, 2012.

33. Cornwall, A. (2008). Unpacking participation: Models, Meanings and Practices. Community Development Journal 43 (3): 269-283.

34. Creswell, J. W. (2007). Qualitative Inquiry and research design choosing among five approaches. (2nd Ed). Thousand Oaks, CA: Sage Publications.

35. De Vaus, D. A. (2014). Surveys in Social Research. (6th ed). Australia: UCL Press.

36. Del Rio, P., \& Burguillo, M. (2009). An empirical analysis of the impact of renewable energy deployment on local sustainability. Renewable and Sustainable Energy Reviews, 13(6-7), 1314-1325.

37. Demeke, Memar Ayalew, \& Solomon, G. (2015). The Millennium Development Goals and the Status of Gender Disparity in Ethiopia: Achievements and Challenges. African Journal of Governance and Development 4 (1): 38-58.

38. Devine-Wright, P., Batel, S., Aas, O., Sovacool, B., Labelle, M. C., \& Ruud, A. (2017). A conceptual framework for understanding the social acceptance of energy infrastructure: Insights from energy storage. Energy Policy, 107, 27-31.

39. Dryden, I. G. C. (1982). The Efficient Use of Energy. 2nd and. London: Butterworth

40. ECA (2014). Energy Access and Security in Eastern Africa-Status and Enhancement 
41. EDC. (2018b). Electricity Access in Rwanda Quadrupled in the Last 7 Years as More Households Get Connected.

42. EDC. (2018a). Electricity Access.

43. ESI-Africa. (2017). Rwanda: Gishoma Peat Power Plant is Grid Ready.

44. EUCL (2018). Incentives to Investors. Energy Utility Corporation Limited.

45. European Small hydropower Association (2004). Environmental group, reserved flow, Short critical review of the methods of calculation. ESHA

46. Federal Democratic Republic of Ethiopia (FDRE). (2017). National Electrification Program

47. Fletcher, A. J. (2017). Applying Critical Realism in Qualitative Research: Methodology Meets Method. International Journal of Social Research Methodology 20 (2): 181-194.

48. Gallagher, M., P. Action, \& Wykes, S. (2014). Civil Society Participation in the Sustainable Energy for All Initiative. In Practical Action Publishing Limited.

49. Gay-Antaki, \& Miriam. (2016). Now We Have Equality: A Feminist Political Ecology Analysis of Carbon Markets in Oaxaca, Mexico. Journal of Latin American Geography 15 (3): 49-66.

50. Geleta, \& Esayas B. (2014). The Politics of Identity and Methodology in African Development

51. Girmay, Y. (2006). Assessing the Environmental Impacts of a Hydropower Project: The case of Akosombo / Kpong Hydropower plants in Ghana Assessing the Environmental Impacts of a Hydropower Project: The case of Akosombo / Kpong Hydropower plants in Ghana.

52. GIZ. (2011). Draft: Ererte Micro Hydropower Plant Handing Over". Unpublished Internal Document.

53. GIZ. (2017a). Energising Development Partnership - En Dev. Country Project Ethiopia." Gollwitzer, L., D. Ockwell, B. Muok, A. E., \& Ahlborg, H. (2018). Rethinking the Sustainability and Institutional Governance of Electricity Access and Mini-Grids: Electricity as a Common Pool Resource." Energy Research \& Social Science 39: 152-161.

54. Gross, \& Catherine. (2007). Community Perspectives of Wind Energy in Australia: The Application of a Justice and Community Fairness Framework to Increase Social Acceptance.” Energy Policy 35 (5): 2727-2736.

55. Guest, G., A. Bunce, \& Johnson, L. (2006). How Many Interviews Are Enough? An Experiment with Data Saturation and Variability." Field Methods 18 (1): 59-82.

56. Hakizimana, J. D. K., and Kim, H.-T. (2016). Peat briquette as an alternative to cooking fuel: a techno-economic viability assessment in Rwanda. Energy 102, 453-464. DOI: 10.1016/j.energy.2016.02.073

57. Hakizimana, J. D. K., Yoon, S. P., Kang, T. J., Kim, H. T., Jeon, Y. S., Choi, Y. C. (2016). Potential for peat-to-power usage in Rwanda and associated implications.

58. Haskamp, Sandra, \& Makonne, K. (2010). Baseline Survey: Small Hydro Power Access to Modern Energy Services in Ethiopia (AMES-E).

59. Heffron, Raphael J., McCauley, D., \& Sovacool, B.K. (2015). Resolving Society's Energy Trilemma Through the Energy Justice Metric." Energy Policy 87: 168-176.

60. Hershowitz, A. (2008). A solid foundation: Belize's chili dam and environmental Decision making. Ecology Law Quarterly, 35(1), 73-105.

61. Hildyard, N. (2008). Dam on the rocks: The flawed economics of large hydroelectric dams The Corner House Briefing. Dorset, United Kingdom: The Corner House.

62. Hossain, M. A. (n.d.). Tipaimukh Hydropower plant of India: Probable Disaster for Bangladesh, 1-23.

63. Huesca-Pérez, Elena, M., Sheinbaum-Pardo, C., \& Köppel, J. (2016). Social Implications of Siting Wind Energy in a Disadvantaged Region: The Case of the Isthmus of Tehuantepec, Mexico." Renewable and Sustainable Energy Reviews 58: 952-965.

64. International River Network (2004). A Critique of the World Bank's Country Assistance Strategy for India, prepared by Ann Kathrin Schneider, International Rivers Network.

65. International Rivers. (2011). About dams. International Rivers.

66. Islar, M., Brogaard, S., \& Lemberg-Pedersen, M. (2017). Feasibility of Energy Justice: Exploring National and Local Efforts for Energy Development in Nepal. Energy Policy 105: 668-676. doi:10.1016/j.enpol.2017.03.004.

67. Kassa, S. (2015). Challenges and Opportunities of Women Political Participation in Ethiopia. Journal of Global Economics 3 (4): 1-7.

68. Kolodinksy, J. (2008). Sampling. Paper presented at the University of Vermont, Burlington, VT. 
69. Kumar, N., \& Quisumbing, A. R. (2015). Policy Reform Toward Gender Equality in Ethiopia: Little by Little the Egg Begins to Walk. World Development 67: 406-423.

70. Kuznets, S., \& Chairman Universities-National Bureau Committee. (1949). Foreword, table of contents. In Problems in the Study of Economic Growth (pp. 3-0). NBER.

71. Lodico, M. G., Spaulding, D. T., \& Voegtle, K. H. (2010). Methods in educational research: From theory to practice (Vol. 28). John Wiley \& Sons.

72. Maingi, J. K., \& Marsh, S. E. (2002). Quantifying hydrologic impacts following hydropower plant construction along the Tana River, Kenya. Journal of Arid Environments, 50(1), 53-79. doi:10.1006/jare.2000.0860

73. Mayring, P. (2000). Qualitative Content Analysis; Forum Qualitative Sozialforschung / Forum: Qualitative Social Research, Vol 1, No 2 (2000)

74. McCauley, D. A., Heffron, H., Stephan, R. J., \& Jenkins, K. (2013). Advancing Energy Justice: The Triumvirate of Tenets. International Energy Law Review 32 (3): 107-110.

75. Meder, K. (2011). Application of Environment Assessment Related to GIZ ECO Micro Hydropower Plants in the Sidam Zone/Ethiopia." [Masther thesis]. University of Heidelberg, Heidelberg, Germany.

76. Ngozwana, N. (2017). Ethical dilemma in qualitative research methodology: Research's reflections. International Journal of Educational methodology. Volume 4,issyue1,19-28.

77. Ngwokabuenui, P. Y. (2013). Principals' attitudes toward the inclusion of students with disabilities in the general education setting: the case of public secondary and high schools in the North West region of Cameroon. Research Journal of Social Sciences \& Management, 2(10), 7-23.

78. Peter, G. \& Pottier, D. (2001). Desertification Convention: Data and information requirements for interdisciplinary research. Proceedings of the international workshop held in Alghero, Italy, 9 to 11 October 1999. Luxembourg: Office for Official Publications of the European Communities.

79. Polkinghorne, D. E. (2005). Language and meaning: Data collection in qualitative research. Journal of counseling psychology, 52(2), 137-145.

80. Sapkota, N. (2000). Using the risks and reconstruction model in resettlement planning: Kali Gandaki Dam, Nepal. The Eastern Anthropologist, 53(1-2), 201-212.

81. Savin-Baden, M., \& Major, C. H. (2013). Qualitative research: The essential guide to theory and practice.

82. Schultz, T. W. (1961). Investment in human capital. The American economic review, 1-17.

83. Sovacool, B. K., \& Dworkin, M. H. (2015). Energy Justice: Conceptual Insights and Practical Applications. Applied Energy 142: 435-444.

84. Sovacool, B. K., Mukherjee, I., Drupady, I. M., \& D’Agostino, A. L. (2011). Evaluating energy security performance from 1990 to 2010 for eighteen countries. Energy, 36(10), 5846-5853.

85. Sovacool, B. K., S. Dhakal, O. Gippner, \& Bambawale, M. J. (2011). "Halting Hydro: A Review of the Socio-Technical Barriers to Hydroelectric Power Plants in Nepal." Energy 36 (5): 3468-3476.

86. Standal, K., and Winther, T. (2016). Empowerment Through Energy? Impact of Electricity on Care Work Practices and Gender Relations. Forum for Development Studies 43 (1): 27-45.

87. Strydom, B. D. (2018). Ethical leadership across cultural value orientations. (Doctoral dissertation, University of Pretoria).

88. Sweetland, S. R. (1996). Human capital theory: Foundations of a field of inquiry. Review of educational research, 66(3), 341-359.

89. Teferi Tessema, \& Girum. (2017). Feasibility Study on Mini-hydroelectric Power Plant for Rural Electrification. Royal Institute of Worldwide Campus, Addis Ababa University.

90. Tigabu, D. G. (2016). Deforestation in Ethiopia: Causes, Impacts and Remedy." International Journal of Development Research 4 (2): 2321-9939.

91. UN Women. (2013). Advancing Gender Equality: Promising Practices. Case studies from the

92. UNDP. (2016). UNDP Support to the Implementation of Sustainable Development Goal

93. Wittwer, G. (2009). The Economic Impacts of a New Hydropower plant in South-East Queensland. Australian Economic Review, 42(1), 12-23. doi:10.1111/j.1467-8462.2009.00506.x 